\title{
PÉCSI TUDOMÁNYEGYETEM
}

Review KÖZGAZDASÁGTUDOMÁNYI KAR

Regionális Politika és Gazdaságtan Doktori Iskola

Iskolavezető: Prof. Dr. Varga Attila

\section{HATÁROK \\ NÉLKÜLI \\ FELSŐOKTATÁS}

Kisebbségi egyetemek regionális és elitképzési szerepe a Kárpát-medencében címü

\author{
doktori értekezés tézisei
}

Takács Zoltán

Konzulens: Prof. Dr. Horváth Gyula

Társkonzulens: Prof. Dr. Gábrity Molnár Irén

PÉCS-SZABADKA

2013 


\section{TARTALOMJEGYZÉK}

1. A témaválasztás indoklása 2

2. A dolgozat felépítése és fejezetei 3

3. Módszertani összegző 3

4. Hipotézisek 5

5. A disszertáció összefoglalása és következtetések 6

6. Tudományos eredmények - a hipotézisek igazolása 13

7. Intézményfejlesztési javaslatok 16

8. Hivatkozások 18

9. A szerző önéletrajza, témához kapcsolódó publikációi és tudományos munkája $\quad 21$

Publikációk $\quad 21$

Konferencia-előadások 24

Tudományos-kutatási projektek 25 


\section{A témaválasztás indoklása}

Az egyetem - a délvidéki értelmiség véleménye szerint - a magyarság szellemi központja lehetne, ahol nem csak magyar nyelvü oktatás folyik, hanem európai és magyar szellemiség is formálódik.

Az egyetemalapítási törekvések - hasonlóan a Kárpát-medence többi határon túli régiójához - több mint tíz évvel ezelőtt, a Vajdaságban is megfogalmazódtak. A folyamatok azonban lassan haladnak. Az általános felsőoktatási légkör - és azon belül a kisebbségi felsőoktatási politika - nehezen tud megbirkózni egy önálló magyar felsőoktatási intézmény alapításának a gondolatával. Egyáltalán nem biztos, hogy a magyar felsőoktatási felzárkóztatási érdek egy magyar nyelvü intézményben érvényesíthető az értékrendszerében, demokráciájában, toleranciájában (és minden egyéb társadalmigazdasági viszonyaiban) hanyatló Szerbiában, még a többnemzetiségű Vajdaságban sem. Egy multietnikus intézmény keretei között szerveződő felsőoktatásnak van és lehet jövője a Vajdaság északi részén, ellenségkép formálása nélkül, a kisebbségi közösség nyelvi elszigetelődésének megakadályozásával - modern, európai szemléletű intézményi megoldások példáját véve alapul. Ezzel a céllal, a „,Szabadkai Egyetem” koncepció újradefiniálására kerül sor a disszertációban.

A Kárpát-medence két, határon túli magyar régiójában (Felvidék, Kárpátalja) létesült új intézmények esettanulmányai (az intézményvezetőkkel készített interjúk) által betekintést nyerhettem a kisebbségi intézmények alapítási-müködési és mindennapi problémájába. Ezeket hasznos tapasztalatokként, a vajdasági intézményfejlesztési kezdeményezések tervezetébe lehetséges beépíteni. A Vajdaság északi részén (a Délvidéken) olyan intézményre van szükség, amely illeszkedik a felsőoktatás európai szerkezeti dinamizmusához (diverzifikálódás, homogenizálódás, nemzetköziesedés, stb.), méltóképpen képviseli a kisebbségi közösség felsőoktatási igényeit (kulturális reprodukció), valamint magán hordozza a területi (decentralizált) és határon átívelő felsőoktatás- és tudományszervezés modern jellemzőit is.

Európai kitekintések, euroregionális szervezödések (EGTC) bemutatását követően a „Szabadkai Egyetem” koncepció létjogosultságát tágabb, államhatárokon átívelö, regionális viszonylatban vizsgálom, a szerb-magyar határrégió felsőoktatásának, képzésiképzettségi, munkaerő-piaci kapacitásainak, gazdasági térszerkezeti jellemzőinek területi elemzéseivel.

Az intézményalapítás helyi társadalom általi támogatottságát, a helyi-regionális elit (magyar-szerb-horvát közösség) képviselőivel készített interjúk során vizsgálom, megszólaltatva a felsőoktatás hatalmi harcát alakító és formáló fó érdekcsoportokat ( $a z$ állami bürokráciát, akadémiai oligarchiát, a piac résztvevőit és további stakeholdereket, hallgatókat, civil szervezeteket, egyházat). Az alapítás szükséges feltételeit is összegzem, figyelembe véve a jogi szabályozást, humánerőforrás-igényeket (oktatók, kutatók), potenciális hallgatók számát, valamint a forrásszabályozási alternatívákat. Rávilágítok továbbá arra, hogy a helyi társadalom számára, milyen gazdasági hatásokkal/elönyökkel jár egy új intézmény, és hogy egy új intézmény milyen széleskörű és szerteágazó, regionálistársadalmi szolgálatokat teljesít/nyújt a lokális közösségben.

Bizonyítani szándékozom, hogy a határon átívelö felsőoktatás- és tudományszervezés (intézményi együttmüködések, kapcsolatok) modellje képezi a „Szabadkai Egyetem” koncepció legitim, racionális és perspektivikus megoldását/lehetőségét. A 2006-ban, a vajdasági magyar helyi-regionális elit néhány képviselője általi megbízatásként megkezdett kutatás (disszertációírás), reményeim szerint, a 2013-as évet kővetően, társadalmilag is hasznosulni fog. 


\title{
2. A dolgozat felépítése és fejezetei
}

\author{
I. Bevezetés \\ II. Felsőoktatás európai és kárpát-medencei kontextusban \\ III. A szerb-magyar határrégió felsőoktatása \\ IV. Szabadka felsőoktatásfejlesztési lehetőségei \\ V. A felsőoktatás regionális-gazdaságfejlesztési szerepe \\ VI. Szerb-magyar határon átívelő intézménykapcsolatok \\ VII. Tudományos eredmények \\ VIII. Összefoglalás és következtetések \\ XI. Intézményfejlesztési javaslatok \\ X. Irodalomjegyzék \\ Mellékletek; Intézményi rövidítések
}

\section{Módszertani összegző}

Tekintettel a téma komplexitására, igyekeztem multidiszciplináris (regionális tudományi-, szociológiai-, földrajz- és politikatudományi) megközelítésben megfogalmazni kutatásom módszertani alapját. Szándékosan empirikus jellegü dolgozat megírását tüztem ki célul, ahol a (mikro)regionális területi szempontok érvényesülnek leginkább (Európa-Kárpátmedence-Magyarország-Szerbia-Szabadka és a határrégió reláción). A dolgozat elméleti alapját Clark (1983) felsőoktatási modellje (illetve Kozma [2002, 2003, 2004, 2005], Papp Z. [2006, 2010a, b, 2012] régióspecifikus és kisebbségi, elméleti megközelítései [ld. 1. ábra]), és Shakamoto-Chapman (2011) (valamint Altbach és szerzötársa [2011], Collins [2011], Knight [2011]) felsőoktatási CBC modellje adja. A felsőoktatás-kutatás további nemzetközi és hazai ismeretanyagait is használom a dolgozatban: Denman (2011), Teichler (2003, 2011), Scott (2011), Salat (2012), valamint Hrubos (2011, 2012) munkáit kiemelve. A felsőoktatás és régiófejlesztés gyakorlati (gazdasági megközelítésü) módszertani alapjait Horváth (2003, 2006, 2010), Rechnitzer és szerzőtársai (2003, 2007, 2011) munkáira (továbbá külföldi szerzők elméleti tanulmányaira: Goddard [2008], Huggins-Johnston [2009], stb.) alapozom. A régióismereti munkák közül Gábrity Molnár (2005, 2006, 2008) tanulmányaira hivatkozom.

1. ábra.

A felsöoktatást befolyásoló érdekcsoportok, kisebbségi közegben 


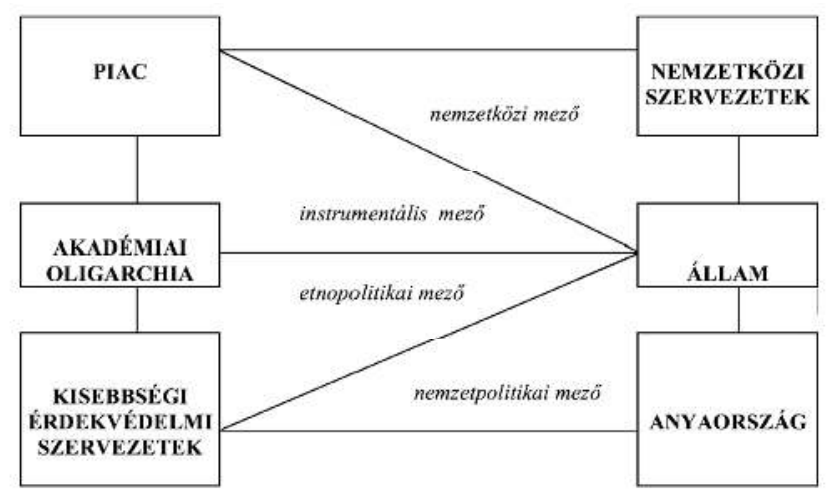

Forrás: Clark, 1983 alapján Papp Z., 2012: 12. o.

1. A dolgozatban használt szekunder adatok:

- szakirodalmi feldolgozás (témakörök: felsőoktatás, kisebbségi és regionális felsőoktatás, határon átívelö régiók és együttmüködések a felsőoktatásban, tudomány és innováció);

- dokumentum-elemzés (a vonatkozó törvények és nemzeti-regionális és lokális jellegü fejlesztési dokumentumok Szerbiában);

- statisztikai adatelemzések (iskolai végzettségi, felsőoktatási, munkanélküliségifoglalkoztatottsági hivatalos statisztikák).

2. A dolgozatban használt primer adatok rögzítése 2009-2012 között (négyéves periódusban) folyamatosan történt:

- Szociológiai, strukturált és félig-strukturált interjúk készültek 73 személy bekapcsolásával (az interjúalanyok, intézmények kiválasztására részletes utalást teszek a disszertáció egyes fejezeteiben):

- intézményvezetökkel Szlovákiában, Ukrajnában, Magyarországon és Szerbiában (új kisebbségi felsőoktatási intézményekben készült esettanulmányok, illetve a szerb-magyar határ menti együttmüködések, intézménykapcsolatok vizsgálata);

- a helyi-regionális elit képviselőivel a Vajdaságban (magyar-szerb-horvát nyelven nyilatkoztak arról, hogy milyen szerepben tudják elképzelni Szabadka felsőoktatását a jövőben);

- hallgatókkal Magyarországon és Szerbiában (tanulmányi migráció és intézményválasztás indoklása).

- Egy fókuszcsoport-vizsgálat készült vajdasági származású doktoranduszokkal (15 személy), akiket egy potenciális új felsőoktatási intézmény foglalkoztathat.

- Több szerbiai és magyarországi adatbázis elemzésére került sor (Educatio Kft, az MTA [szerbiai] Külső Köztestületi Tagságának katasztere, a Vajdasági Magyar Doktoranduszok és Kutatók Szervezetének tagsági katasztere, Foglalkoztatás-ügyi Hivatal, illetve a Vajdaság Autonóm Tartomány Tartományi Oktatási és Müvelődési Titkárságának adatbázisai).

A kutatási terep föbb színhelyei: Révkomárom (Szlovákia); Beregszász (Ukrajna); Szeged, Baja, Kecskemét, Pécs, Dunaújváros, Budapest, Gödöllő (Magyarország); Szabadka, Zenta és Újvidék (Szerbia).

Kutatási cél: az empirikus kutatások (és szekunder adatok) által bizonyítani azokat a felvetett hipotéziseket, amelyek Szabadka intézményesülő/önállósuló felsőoktatásához szolgáltatnak alapot. A határrégió (elsősorban Szabadka-Szeged vonatkozásában) 
társadalom-gazdasági, versenyképességi és felsőoktatás- és kutatásfejlesztési lehetőségei, felzárkóztatása a cél, európai szemléletủ intézményi keret- és feltételrendszerben.

\section{Hipotézisek}

H/1. A határon túli (magyar kisebbségi) intézmények alapítása mérsékelte a tanulmányi célú migrációt a Kárpát-medencében, pozitívan hozzájárulva a kisebbségi közösségek elitmegtartási törekvéseihez.

H/2. A határon túli magyar felsőoktatás (a kisebbségi intézmények vonatkozásában) illeszkedik a felsőoktatás nemzetköziesedési folyamataihoz, ugyanakkor a differenciálódási/diverzifikálódási feltételeknek nehezen tud eleget tenni.

H/3. A határ két oldalán (a határon átívelő régióban) eltérő oktatás- és tudományszervezési gyakorlat van jelen, a szerb oldalon megnyilvánuló, konzerválódó felsőoktatási-regionális egyenlőtlenségekkel.

H/4. Felvetésem, hogy a felsőoktatás-fejlesztés egy integrációs-felzárkóztatási stratégia mentén valósítható meg a szerb-magyar (államhatárokon átnyúló) határrégióban, európai léptékű fejlesztési (és intézményi) keretek között.

H/5. Szabadka mint önálló felsőoktatási központ szerepe tisztázatlan a régióban. A helyi és regionális elit intézményfejlesztési szándéka bizonytalan.

H/6. Szabadkán multietnikus alapokon szerveződő, állami alapítású intézményi koncepciónak van létjogosultsága, a határ(ok) és társadalom felé nyitott, modern tudományszervezési és regionális szolgáltatói magatartásformával.

H/7. A szerb-magyar határon átívelő intézményi kapcsolatok/együttműködések lehetőségei nincsenek kellőképpen kihasználva, nincs racionális és reális munkamegosztás, erőforrás-kihasználás, és hálózatszerüen müködtetett együttmüködés a határrégióban.

\section{A disszertáció összefoglalása és következtetések}

Az egyetemek már a középkor óta Európa gazdasági és társadalmi fejlődésének legfontosabb intézményei. Folyamatos változás jellemzi a felsőoktatás- és tudományszervezés - a „tudás bástyáinak” müködését. A XX. század második felétől a differenciálódás, diverzifikálódás, homogenizálódás, létszámexpanzió folyamatait jeleníti meg a felsőoktatás, amely mind nagyobb komplexitást eredményez napjainkban. Egyben a hatalmi harcok színtereként jelenik meg (akadémiai oligarchia, állami bürokrácia, piac és más érdekcsoportok), ahol változó szerkezeti dinamizmusok (intézményi és regionálisterületi koncentráció) jutnak kifejezésre. A diverzifikálódás szellemében, a sokféleség 
érték Európában, a globalizáció hatására kialakuló nemzetköziesedés folyamatai pedig új kihívásokkal szembesítik a felsőoktatási intézményeket.

A nemzetköziesedés mentén, a XXI. század felsőoktatásának sarkalatos pontjai: erös menedzsment és stratégia, erős kormányzás, minőség, társadalmi relevancia (foglakoztathatóság, tudásgazdaság, esélyegyenlőség-szociális dimenzió, meritokrácia), mobilitás, sokszínüség és erős, szerteágazó hálózatok/hálózatépítési törekvések és együttmüködések.

Kelet-Közép-Európa rendszerváltó országai egyszerre szembesülnek a nemzetköziesedés és nemzetépités törekvéseivel, amely eredményeként új intézmények jönnek létre (az új politikai-kulturális és társadalom-gazdasági berendezkedés számára lojális elit és szakértői réteg kinevelését megcélozva). Mivel a kisebbségek világszerte alulreprezentáltak az egyetemi képzésben, így a '89/90-es változások közepette, a megfelelő alkalmat megragadva, a kisebbségi helyi-regionális elitek is önálló intézmények alapításába kezdenek. A Kárpát-medence két intézményét (Selye János Egyetem [Révkomárom, Szlovákia] és a II. Rákóczi Ferenc Kárpátaljai Magyar Főiskola [Beregszász, Ukrajna]) alapul véve és elemezve látható, hogy ezek az intézmények illeszkednek a felsőoktatás nemzetköziesedési folyamataihoz (kihelyezett képzések, tanulmányi célú mobilitás). Ugyanakkor a diverzifikálódási feltételeknek nehezen tudnak eleget tenni (színes képzési programok, sokoldalú, regionális szolgáltatói készség, pénzügyi stabilitás, modern, európai multikulturalizmus és többnyelvüség).

2. ábra

A magyar felsőoktatásba jelentkezö határon túli állampolgárok az oktatás helyszíne szerint, 2005-2010, fö

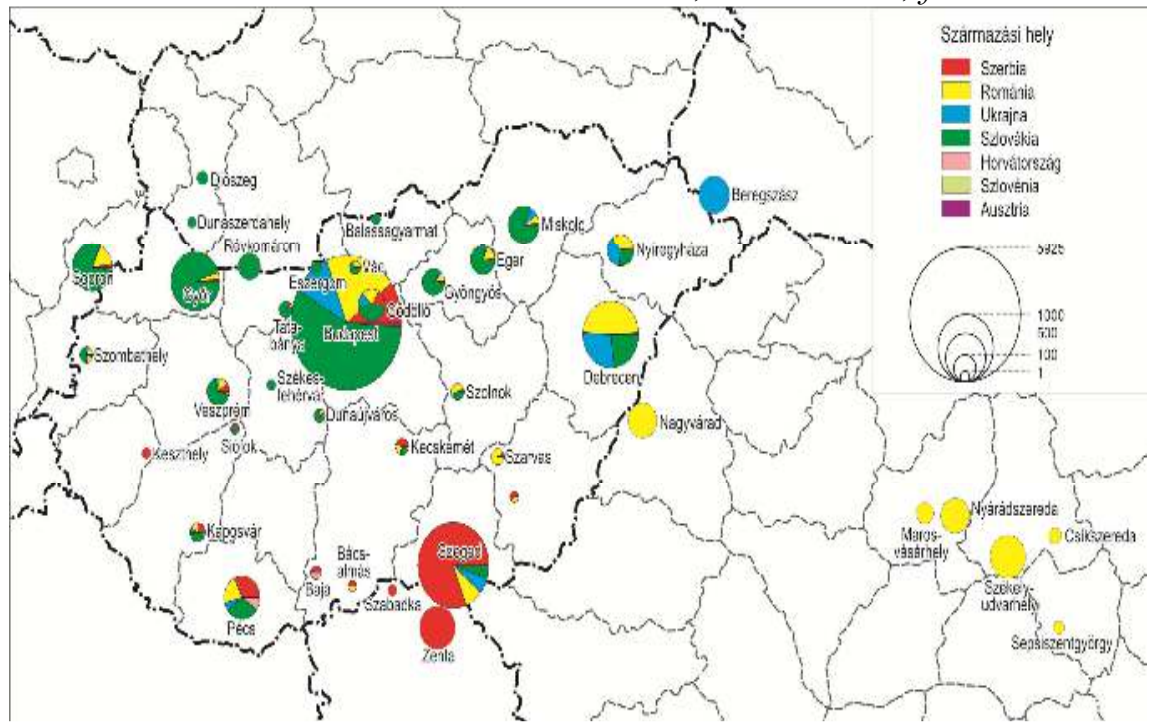

Forrás: Educatio adatbázisa alapján saját szerkesztés (N=14 284); Kartográfia: Dr. Tátrai Patrik, MTA CSFK FTI, 2012.

Megjegyzés: A határon túli jelek a magyar felsőoktatási intézmények külföldi kihelyezett felsőoktatási intézményeit jelölik.

A kárpát-medencei felsőoktatás nemzetköziesedésének egyik sarkalatos pontja, a '90-es évektől egyre intenzívebbé váló tanulmányi célú mobilitás/migráció. A magyar felsőoktatás ösztöndíj- és támogatáspolitikája, valamint a kihelyezett képzések által vált részesévé a nemzetköziesedés folyamatainak. A határon túli hallgatók közül legtöbben budapesti felsőoktatási intézményekbe jelentkeznek felvételire $(49,4 \%)$, majd a többi hallgató Szegedre (13,1\%), Debrecenbe $(9,3 \%)$, Győrbe $(5,8 \%)$, Sopronba $(3,9 \%)$ és 
Pécsre $(3,0 \%)$ - (ld. 2. ábra). A szerbiai hallgatók (a teljes vajdasági magyar hallgatói létszám 30\%-a) esetében a földrajzi közelségnek van meghatározó szerepe: Szegedre jelentkezik a hallgatók 52\%-a. Magyarországra - tanulmányi célokkal - Szerbiából Szabadkáról (23\%), Magyarkanizsáról (20\%), valamint Zentáról (17\%) érkezik a hallgatók kétharmada. A kárpát-medencei határon túli régiók kibocsátó területei között első helyen szerepelnek a magyar etnikai tömb városai, mint például: Komárom $(7,7 \%)$, Dunaszerdahely (7,2\%), Érsekújvár (5,5\%), Szabadka (4,4\%), Magyarkanizsa (3,7\%).

Az elmúlt közel húsz évben összesen 4 országban, 13 helyen indultak kihelyezett képzések a Kárpát-medencében (például: Révkomárom, Zenta, Beregszász, stb.), ami ma a magyar felsőoktatás által felkínált képzési helyek 4,5\%-át teszi ki. Szerepük az új önálló intézmények létrejöttében volt meghatározó.

A kárpát-medencei (kisebbségi) intézmény-és elitformálási folyamatok a felsőoktatási szereplők kemény harcával és a változásmenedzserek hosszadalmas küzdelmével jellemezhetők. Általában minden országban dominál az államnacionalizmussal szembeni, a „kisebbségvédelem” elvei mentén szerveződő intézményfejlesztés. A határon túli magyarság szellemi központja, a felvidéki magyarok esetében Révkomárom, a kárpátaljai magyarok esetében Beregszász, a délvidéki magyarok esetében Szabadka.

Az intézményalapítást megindító (nélkülözhetetlen) politikai akarat egysége megrendül, amennyiben az egyéni érdekek (politikai elit és akadémiai oligarchia) a kollektív érdek fölé helyezkednek (pl. Komárom-Nyitra, Beregszász-Ungvár, Szabadka-Újvidék - akadémiai körök érdekellentéte). Az önálló magyar egyetemet a magyar anyanyelvü helybeli tanárok bizalmatlansági és egyéni érdekek miatt „nem fogadják el”. Alapítvány létrehozásával indulnak el a kezdeményezések, amelyekben a város is aktív szerepet vállal. A városvezetés nélkül nem lehet az alapítást véghezvinni. Szövetségekre van szükség, amelyek a politikai elit és „, a kisebbségi felsőoktatás ügyét támogatók” (akadémiai elit, helyi értelmiség, egyházi és más érdekcsoportok) között köttetnek, a kölcsönös egymásrautaltság elve alapján. A többségi nemzettel kötött szövetség nem müködik. Nem tudják a kárpát-medencei (határon túli) új intézmények a multikulturalizmus mentén szerveződő (nyelvi elszigetelődést, ellenségeskedést megakadályozó), perspektivikus és modern, európai felsőoktatási mintákat átörökíteni. Az új, kisebbségi intézmény esetében cél, hogy magasan képzett magyar fiatalok diplomázzanak a szülőföldjükön (javuljon a közösség hátrányos, alulreprezentáltság-helyzete, mérséklődjön a migráció), akik kulcskompetenciákkal rendelkeznek, elhelyezkedhetnek az állami szférában, vagy önfoglalkoztatásba kezdenek, amellyel a kisebbségi társadalom kulturális reprodukciója valósul meg.

Financiális és döntéshozatali önállóság és hosszú távú fönntarthatóság megvalósítása a cél, ahol az anyaországi támogatások kiegészítő jellegüek, a minőségi oktatás feltételeinek megteremtését szolgálják. A kutatás, tudományszervezés intézményesítése, valamint a határon átívelö kapcsolatok, hálózatépítések fejlesztése képezik a prioritást.

A kárpát-medencei határon túli példák, müködőképes gyakorlatok, nehézségek tapasztalataiból építkezve, a vajdasági magyar intézményfejlesztési törekvéseket egy szélesebb, államhatárokon átívelő felsőoktatási közegen belül vizsgálom. A szerb-magyar határvonalon megjelenő újszerű határmozgások (ingázó hallgatók, vállalkozások, intézményi kapcsolatok, stb.) és a felsőoktatás kiemelt szerepe hozzájárulnak ahhoz, hogy a közös határt mint egy innovációs tengelyt kezeljük (érvényesítve a nagyvárosok, hagyományok szempontját is), egy - a hétköznapi regionalizmuson alapuló - határrégiót formálva. Ez egyben továbbfejlődést, felzárkózási stratégiát is jelent a szerb oldal számára (komplex társadalom- és gazdaságfejlesztési feladatokat is ellátva). A vizsgált területet funkcionális régióként kell kezelni, amelynek a fejlesztési feladatok korszerü, a 
szubszidiaritás elvét is érvényesítő és Európa-orientált ellátása céljából, egy szupranacionális közigazgatási rendhez kell igazodnia, az európai területi együttmüködési csoportosulások (EGTC-k) intézményrendszere által. Az EGTC-k több éves gyakorlata (az együttmüködési formák sokrétüsége) bizonyítja a felsőoktatás és kutatás területén elért sikerességüket. Az együttműködések sarkalatos pontja a multikulturalizmus (európai példák: „Pyrenees Mediterranean” Eurocampus [katalán-francia-spanyol], „HelsinkiTallin Science Twin City" [észt-finn]).

A szerb-magyar határrégió felsőoktatás-fejlesztési lehetőségeit vizsgálva, Szabadka és a szerbiai határ menti, vidéki intézmények stagnálása/visszafejlödése látható (a hallgatói létszám alakulásának példája: 2009/2001 Újvidéken 68\%-kal, a Vajdaságban 44\%-kal, míg Szabadkán mindössze 13\%-kal nőtt a hallgatók száma, beiskolázási, kvótafeltöltési problémák jelennek meg). Elkülönül, periférikus helyzetbe kerül a szerb határrégió a magyarországi határrégió viszonylatában is (1 000 lakóra jutó hallgató példája: Szegeden 129,5, Szabadkán 30,7, kimagasló humán- és társadalomtudományi részaránnyal). A kisebbségi problémákkal (is) küszködő régió további jellemzői: az egyes nemzeti közösség alulreprezentáltsága a felsőoktatásban, a felsőfokú végzettséggel rendelkezők alacsonyabb részaránya, szükös, anyanyelven elérhető képzési kínálat. Részben ezzel is magyarázható, hogy a hallgatók egyre nagyobb számban és részarányban (cca. 30\%) tanulnak Magyarországon. A vajdasági magyar hallgatók (4 700-5 200 fó) 42\%-a Szabadkán és Szegeden tanul, így valójában a határ két oldalán lévő intézményekben koncentrálódik a legtöbb magyar hallgató. A nemzethatárokon átívelő régióban egy 36000 főt egybefogó, (hipotetikus) határon átnyúló campus rajzolódik ki (ezen belül az észak-vajdasági hallgatói létszám $7500-8000$ főt egyesít). A szerb-magyar határrégiót egészében vizsgálva kimagasló az oktatás (19,9\%), a mủvészetek, bölcsész- és humántudományok $(15,1 \%)$, a természet-, matematika- és informatikatudományok (18,0\%), valamint az egészség- és szociális tudományok $(11,4 \%)$ részaránya, amely a regionális versenyképesség és innovatív-teljesítőképesség szempontjából fejlődési potenciált hordoz. Ehhez az együttmüködések proaktív és modern formája szükséges, a közös erőforrásokat maximálisan kihasználva, a nagyvárosok intézményeinek bekapcsolódásával (Szabadka, Szeged, Zombor, Baja, illetve Újvidék és Budapest is).

A határon átívelö felsőoktatási együttmüködések „potenciális felületei”: müszaki tudományok, természettudományok és matematika, bölcsészettudományok, művészeti képzések és egészségtudományok (kiegészítve a határ egyik és másik oldalán megjelenő hiányosságokat). A tanító- és óvóképzés, valamint a közgazdászképzések túldimenzionáltak (Szerbiában a munkaerö-piaci aktuális helyzet is ezt tükrözi). $A$ reálgazdasági folyamatok (a társadalmi-gazdasági térszerkezet változása, reformok, a piac változása) és az oktatási rendszer rugalmatlansága miatt (a betöltetlen szabad munkahelyek és a munkanélküliek számának mérlege, képzési területenként) eltérések tapasztalhatók. A legnagyobb eltérés a pedagógiai-, bölcsész-, természet- és társadalomtudományi képzési területen mutatkozik meg. Nagyobb a szabad munkahelyek száma (136\%), mint a munkanélküliek száma (felsőfokú végzettség esetében). Tanárok (bölcsész- és természettudományi szakirányú) képzésére van szükség a régióban. Más képzési területeken (pl. müszaki) profilváltás szükséges, illetve mesterképzési-szakstúdiumi (multidiszciplináris) és átképzési rendszer fejlesztése jelenthet megoldást, minimális intézményi kvótákkal, egy-két éves periódusban futó, speciális szakirányú képzésekkel. Az oktatási rendszernek (illetve az autonóm felsőoktatási intézményeknek) kell megfelelő, újratervezett (kereslet-irányultságú), flexibilis platformot biztosítania, amelybe a határon túli partnerek is be tudnak kapcsolódni.

A határon átívelő felsőoktatás- és tudományszervezés - Szabadka marginalizálódásának példájából kiindulva - több okból is indokolt. Szerbiában az állami 
bürokrácia szerepe tradicionálisan nagy, a felsőoktatás politikailag átszőtt. Nagyon erős a központi-minisztériumi hatalom befolyása, illetve a belgrádi lobbi (akkreditáció, törvénykezés, stb.), érdektelenség van jelen a kisebbségi igényekkel szemben (pl. kétnyelvű oktatás), a regionális gazdaság, munkaerőpiac elvárásai nem számítanak mérvadónak. Egyre több magánintézmény jelenik meg a régióban. A magán felsőoktatási intézmények rugalmasabban reagálnak az igényekre, mint az állami karok, viszont nem tudnak minőségi oktatást biztosítani (hétvégi kurzusok, átmeneti akkreditáció). Maga a piac elvárása sem tud a felsőoktatáson keresztül kifejezésre jutni, mert az állam és az akadémiai oligarchia kezében tarja a „felsőoktatás színterét”, hagyja a folyamatokat vakvágányra futni (diplomás munkanélküliek). Az akadémiai oligarchia befolyása nagy, és szerepük egybemosódik „más” érdekszférákkal (politikusok, magánintézmények tulajdonosai is egyben). Szabadkán jellemző az Újvidéki Egyetem erős befolyása, a magyar érdekeltségü karok függősége, a belgrádi akadémiai oligarchia és magántőke érdekének helyi érvényesülése és hasznosulása. A számadatok a felsőoktatás erős centralizációs és koncentrációs irányzatait jelenítik meg: a régió felsőoktatásában, ahol a vidéki képzőközpontok szerepe, helyzete, regionális beágyazottsága nem tud megerősödni, inkább visszafejlődés tapasztalható. Szabadka szintjén láthatjuk lecsapódni azt az általános problémát, amely a szerb felsőoktatást (általánosságban) jellemzi: az állami bürokrácia szabad piaci feltételeknek ad teret, amelyböl az akadémiai oligarchia is hasznot húzhat. Így lényegében minden érdekcsoport (az egyetemistákat és adófizető polgárokat, kisebbségeket, a gazdaságot leszámítva) sikeresen tudja „csillapítani” és fenntartani ezt a helyzetet, látszólagos egymásrámutogatás mellett is.

Szabadka felsőoktatása megoldásra vár. Integrációs kényszerekkel szembesülve, önálló felsőoktatási „bázisintézmény” létrehozása képezheti a megoldás első lépését. A Vajdaság Autonóm Tartomány korlátozott jogkörökkel rendelkezik, felsőoktatási intézmény alapítását azonban kezdeményezheti. A nemzeti tanácsok megalakulásával a kisebbségi oktatáspolitizálás és érdekérvényesítés határozottabb intézményi háttere konstruálódik (a Magyar Nemzeti Tanács [MNT] példája: szerb nyelvoktatás, felvételi felkészítések, egyetemi tanulmányok és hiányszakmák ösztöndíjazása a magyarság esetében, demográfia, egyszerüsített diplomahonosítás, stb.), bár nemzeti szinten az „etnikai hatalmi harcok” továbbra is jelen vannak.

Szabadka tradicionálisan többnemzetiségü: magyar, szerb, horvát/bunyevác (35,7\% magyar, 27,0\% szerb, 10,0\% horvát, 9,6\% bunyevác) nemzeti közösségek által lakott, 100000 fơs város (viszonyításként: Révkomárom lakossága 35 000, míg Beregszászé 25000 fö, magyar nemzetiségi abszolút többséggel). Tekintettel Szabadka város specifikus etnikai összetételére, nagyságára, a városban működő állami (nem önálló) felsőoktatási intézményekre (Építőmérnöki Kar, Közgazdasági Kar, Magyar Tannyelvü Tanítóképző Kar, Müszaki Szakfőiskola, Óvóképző Szakfőiskola), az elmúlt 10 évben többször is felvetődött az egyetemalapítás kérdése (2002-ben, 2006-ban, 2010-ben), magyar és szerb (elkülönülő) kezdeményezések formájában. A horvát közösség szintén számot vetett a felsőoktatás fejlesztésével kapcsolatos igényeivel (tanító, kroatisztika tanszék), azonban ezeknek a különböző kezdeményezéseknek egyike sem valósult meg. A 2012-es év végén, majd 2013 tavaszán, a Magyar Nemzeti Tanács kezdeményezésével újra napvilágot lát a „Szabadkai Magyar Egyetem”, illetve a „magyar nyelven (is) oktató állami egyetem” témája. A kezdeményezés realitása nagymértékben megkérdőjelezhető, mégpedig a helyiregionális elit, az akadémiai elit és a szabadkai székhelyü intézmények vezetőinek álláspontját, a politika és a nemzeti tanácsok meglátását, valamint a szükséges és egyben nélkülözhetetlen feltételeket (jogi-, humán- és pénzügyi kondíciókat) mérlegelve. A magyar, szerb és horvát nemzetiségeket képviselő helyi-regionális elit véleménye szerint a potenciális új intézmény nemzetiségi- és nyelvi-szervezési kérdéseivel kapcsolatosan - 
multietnikus felsőoktatási intézménynek van igazán létjogosultsága Szabadkán. Az önálló magyar egyetem gondolatát a vajdasági magyar közösség elveti (a közösség kicsi lélekszámú, kevés diákkal és tanárral, szerény képzési palettával). Szükség van Szabadkán a többségi (és más) nemzetiségü hallgatókra, tanárokra, valamint arra az intézményre, amely kizárólag alulról történő építkezéssel, a magyar-szerb-horvát közösségekkel kötött szövetségek segítségével (egyúttal azok igényeit is kielégítve), megfelelőképpen képviselni tudja a vajdasági magyarság érdekét is.

Az intézményalapítás helyi-regionális elit általi támogatottságát vizsgálva, két elkülönülő csoport jelenik meg: a „,támogatók” és „,nem támogatók”csoportja. A szerb vezetőségü karok és a szerb akadémiai elit (újvidéki egyetemi elkötelezettség, munkahelyük stabilitása, a potenciális intézménnyel szembeni bizalmatlanság miatt) nem támogatják a Szabadkai Egyetem koncepcióját, viszont jogi-, humán-és pénzügyi kondícióik megfelelőek. A vajdasági magyar akadémiai elit hozzáállása is bizonytalan. A magyar érdekeltségü felsőoktatási intézmények nem tesznek eleget az egyetem megalakításához szükséges, önálló kari szervezési formának (legkevesebb három akkreditált képzési program, három szinten [BSc, $\mathrm{MSc}, \mathrm{PhD}])$. A magánkarokat képviselő intézményvezetők és akadémiai elit szeretne együttmüködni (viszont mások nem szeretnék az állami-magán vegyes alapítást). Az egyház mérsékelt, elzárkózó magatartást mutat (viszont szeretné megtalálni helyét egy jövőbeli intézményben, egy potenciális vallástudományi kar alapításával). A városvezetés (amely 2008 óta többségében szerb érdekeltségü) támogatja az egyetem létrehozását, rendelkezik elképzelésekkel (múvészeti kar létrehozása). A Magyar Nemzeti Tanács szintén támogatja (kezdeményezi) az alapítást, viszont a két fő támogató fél között (városvezetés, MNT) kitapintható egy ellentét: $a$ nemzetiség és az oktatás nyelvének kérdése. Ehhez tárgyalások kezdeményezésével meg kell találni a kompromisszumot, nagyobb figyelmet szentelve a nemzeti tanács(ok) oktatásfejlesztési törekvéseinek, és a már említett nemzetiségi (magyar-szerb-horvát) szövetségek kialakításának.

A felsőoktatási törvény által biztosított lehetőségek ismeretében, valamint a helyi intézményi kapacitások mérlegelésével, középtávon egy „Szakstúdiumi Akadémia” (,,önálló, regionális felsőoktatási intézmény”) hozható létre Szabadkán (oktatói, kutatói, tudományos és müvészeti tevékenységeket egyesítve, három tudományterület lefedésével, legkevesebb öt akkreditált képzési programmal, két szinten [alap: szakstúdiumok, valamint „középszinten”: specializációs szakstúdiumok]). Egy ilyen intézmény független az újvidéki egyetemi struktúráktól (magyar érdekeltségü intézményvezetéssel), lehetőséget biztosítana egy regionális szinten szerveződő felsőoktatási intézmény megalapozásához, amely a későbbiek folyamán, akár egyetemi szintre is emelhető lenne, komoly intézményfejlesztési erőfeszítések mellett, hosszú távú fejlesztési stratégiában gondolkodva, ugyanakkor könnyen áthidalhatná a kezdeti alapítási nehézségeket. A (hiányzó) harmadik tudományterület lefedésére két megoldás létezik: természettudomány és matematika (korábbi munkaerő-piaci és gazdasági térszerkezeti indokoltsággal, kétszakos tanárképzés formájában) és művészetek (többnemzetiségü közösség regionális, kulturális örökséget ápoló, müvészeti hagyományok és identitásőrzés intézményeként, a városvezetés támogatásával). Fontos, hogy multidiszciplináris képzési profilok tegyék változatossá a kínálatot (környezetvédelem, agrár, jog- és müszaki tudományokat is ötvözve). A humánfeltételeket illetően a (multietnikus) közösség rendelkezik megfelelő kapacitásokkal (potenciális 150-250 felsőoktatási alkalmazott, Szabadkán cca. 6 500-7 000 hallgató van pillanatnyilag). A financiális feltételeket mérlegelve, az alapításban érdekelt szabadkai intézmények pénzelése már megoldott, az alapítás, intézményi infrastruktúra és a harmadik tudományterületet képviselö képzési program igényel támogatásokat (tartományi és 
magyarországi). Ezzel egy önálló, Vajdaságban egyedülálló, multietnikus felsőoktatási intézmény jöhetne létre Szabadkán, európai értékeket képviselve.

A helyi társadalmak, városok számára egy felsőoktatási intézmény fontos szellemi, de ugyanakkor gazdasági bázist is jelent. Az intézmény helyi gazdasági hatásai a következőkben jutnak kifejezésre: munkaerő alkalmazása, a helyi jövedelmek növekedése, a helyi vállalkozások, beszállítók növekvő megrendelései, a hallgatói szükségleteket kielégítő szolgáltatások megjelenése (elszállásolás, étkeztetés, szórakozás, stb.), illetve azok továbbgyürüző (multiplikatív) hatásai. Az intézmények tudástermelö, humánerőforrás-fejlesztő, kutatás-fejlesztési tevékenységekből származó, hosszabb távon kifejezésre jutó hatásai mellett, a városban új kulturális igények jelennek meg, pozitívan alakul a város arculata, szellemi pezsgése, presztízse, amely új gazdasági szereplőket vonz, és a helyi társadalom megtartó erejét növeli. Szabadkán a felsőoktatási intézmények elsődleges szerepe - az oktatás dominál. A lokális gazdaság erőtlensége, ipari vállalatok hiánya miatt sincs a felsőoktatási intézményeknek valós kapcsolata a gazdasággal (vidéki intézményként halmozott hátrányokat elszenvedve). A felsőoktatás-és kutatásfejlesztés a régió (egyben a kisebbségi közösség) számára a regionális gazdaságfejlesztés eszköze is. Ezzel sikeresen operálni csak úgy tud, ha az ország/nemzet regionális fejlesztési távlatait/érdekeit nem keresztezi, ugyanakkor a helyi-regionális elit érvel és harcol az intézményalapítás/intézményfejlesztés mellett, ösztönzi a felsőoktatás és a regionális fejlődés szoros együttműködését, ágazatközi koordinációt fejleszt, ösztönözve a kutatást, technológiai és gazdasági innovációkat, tudományos transzfert. Ezek egyben a fenntarthatóság mércéi is, és ezeket a fejlesztési lehetőségeket (intézményváltozási kényszereket) integrálni kell az önálló felsőoktatási koncepcióba, Szabadka esetében.

A határok nélküli felsőoktatás (kölcsönös fejlesztési és felzárkóztatási) komoly intézményi kapcsolatok kiépítésével valósítható meg, amely Szabadka felsőoktatása során mindenképp prioritást kell, hogy élvezzen. A kutatási tapasztalatok azt bizonyítják, hogy az intézményi kapcsolatok/együttmüködési formák (integráció, nyitás) lehetőségei nincsenek kellőképpen kihasználva a szerb-magyar határrégióban. Nincs racionális és valós munkamegosztás és hálózatszerüen müködtetett együttmüködés a régióban. Párhuzamos képzések folynak a határ két oldalán. A magyarországi felsőoktatási intézmények jelentős „merítési bázisai” a vajdasági magyar hallgatók. Reciprocitási alapon működik (igaz, kis arányban) a tanárcsere. Az együttműködés más, innovatív formái megjelennek a kisebb (magyar érdekeltségü) karok, főiskolák esetében (közös képzési programok akkreditálása, kettős diplomakiadási programok). Ezek az intézmények keresik a regionális együttműködés minden tartalmat lefedő vertikumát (EU-s pályázatok, közös képzések, szakok indítása, konferenciák, tanár- és diákcsere, publikációs lehetőségek, stb.). A nagyobb intézmények az együttmúködés terén (nagy hallgatói létszám, hagyományok, erős helyi oktatói gárda) inkább a nagy intézmények, a centrumok felé gravitálnak: Budapest, Újvidék és Belgrád. A szerb-magyar határrégióban különösen erős integrációs szándék nyilvánul meg a szerbiai Szabadka központú intézmények esetében, tipikus magyar-magyar viszonyok formájában. A CBC együttmüködések nem képezik minden intézmény missziójának szerves részét, holott kétoldali benefit-hatást élvezhet minden partner (kapacitás-építés, elismerés, nemzetpolitikai aspirációk, stb.). Szervezeti szinten a partnerek viselkedése/motivációja sokszor különbözö (a szerb partner érdektelensége, időés munkabefektetés hiánya). Pénzügyi szempontból - a határon átívelő programok támogatása IPA forrásokból valósult meg az elmúlt időszakban (sokszor bizonytalanság, felkészületlenség, megfelelő intézményi tudás hiányában). Az együttmüködések sikerességét országspecifikus szabályozás (vendégtanári viszony, akadémiai fokozatok elismerése), szupranacionális (EU-s szabályozás) tényezők, továbbá a politikai stabilitás, illetve a kisebbségi közeg által hordozott „feszültségek” is befolyásolják. Az 
együttmüködések individuális tényezői között az egyének nemzetközi kapcsolatai, ismeretsége a meghatározó, amelyet az intézményvezetés tovább erősíthet, támogathat, segíthet.

A határ menti régiók föllenditésében fontos szerepet játszhatnak a regionális felsőoktatási intézmények, kis hallgatói létszámmal, rövid képzési ciklussal, majd a „továbblépéshez” szükséges egyetemi kooperációs törekvésekkel (kredittranszfer), valamint a helyi, „naprakész” szükségletek alapján kialakított képzési programokkal. A vajdasági magyar felsőoktatás célja a megfelelő kínálat biztosítása lehet, amelyhez támogatni kell a magyar fiatalok számára a felsőfokú végzettség megszerzését, elsősorban magyar nyelven, a lakóhelyükhöz közel, csökkentve a tanulmányi célú migráció általi agyelszívás kockázatát. Mindez piacképes szakokkal oktató, innovatív szerepköröket magukra vállaló határon túli intézmények „program-importjai” által valósítható meg (az angol nyelvű oktatás iránti nagy igényt is figyelembe véve). A határon átívelő együttmüködésekkel erösíthetök ezek a mechanizmusok, ugyanakkor a területfejlesztés modern eszközeivel, a regionális fejlesztésekkel a térség egyébirányú felzárkóztatása is megvalósítható.

\section{Tudományos eredmények - a hipotézisek igazolása}

1. A határon túli (magyar kisebbségi) intézmények alapítása mérsékelte a tanulmányi célú migrációt a Kárpát-medencében, pozitívan hozzájárulva a kisebbségi közösségek elitmegtartási törekvéseihez. A Magyarországon tanuló külföldi hallgatók részarányához viszonyítva kifejezetten Románia és Szlovákia esetében csökkent jelentősen a Magyarországon tanuló hallgatói arány (Románia esetében abszolút számokban is). Az ukrán hallgatók esetében is csökkenő tendencia figyelhető meg. Másrészt, a határon túli intézményfejlesztések és kihelyezett képzések által, a felsőoktatási súlypont folyamatosan Magyarország határain kívülre helyezkedett. Egyre több hallgató kapcsolódott be a felsőoktatási intézmények kihelyezett képzésébe a szülőföldjén, majd az újonnan alapított intézményekbe (a szlovák és ukrán új, kisebbségi intézmények a helybeli magyar hallgatók 45-50\%-át tömörítik), amelyek részben a kihelyezett képzések „leválásával” jöttek létre. Így ezek az intézmények pozitívan járultak hozzá a kisebbségi közösségek elitmegtartási törekvéseihez.

2. A határon túli magyar felsőoktatás illeszkedik a felsőoktatás nemzetköziesedési folyamataihoz (kihelyezett képzések, hallgatói mobilitás), ugyanakkor a differenciálódási/diverzifikálódási feltételeknek nehezen tud eleget tenni (színes képzési programok, sokoldalú, regionális intézményi szolgáltatókészség, pénzügyi stabilitás, modern, európai multikulturalizmus és többnyelvűség). Általában kevés oktatóval, szükös képzési kínálat mellett, pénzügyi (fenntartói-támogatói) függőségben szerveződik a határon túli magyar felsőoktatás (II. RFKMF, Beregszász, illetve az SJE, Révkomárom példáiból kiindulva). A nyelvi elszigetelődés nagy probléma, a multikulturalizmus nem tud az intézmények missziójába beépülni. A társadalom és a gazdaság felé irányuló intézményi szolgáltatások gyengék. Az önálló, kisebbségi felsőoktatási intézmények szerepe a kisebbségi közösség kulturális reprodukciójában, 
társadalmi pozíciójának erősítésében, helyben maradó kisebbségi értelmiség kinevelésében nyilvánul meg.

3. Kutatásaim során bizonyítást nyert, hogy a szerb-magyar határ két oldalán (a határon átívelő régióban) eltérő oktatás- és tudományszervezési gyakorlat van jelen. A határ szerbiai oldalán konzerválódó felsőoktatási-regionális egyenlötlenségek jelennek meg (fokozódó esélyegyenlőtlenség a kistérségek, falu-város, és a kisebbségek vonatkozásában, továbbá kedvezőtlen tudományterületi megoszlás, hiányos felsőoktatási kínálat). A kiegyensúlyozatlan intézményi területi koncentráció (Újvidék-Szabadka) periférikus helyzetbe sodorja a Szabadka környéki intézményeket. A gazdasági térszerkezet átalakulását és a munkaerőpiac igényeit nem követi megfelelően és hatékonyan a felsőoktatás. Tanárok (bölcsész és természettudományi szakirányú) képzésére van szükség a régióban, ugyanakkor közgazdász-menedzser és tanító dömping van. A határon átívelő régió (36 000 főt egybefogó, hipotetikus campusszal) a regionális versenyképességi- és innovatív-teljesítőképességi szempontok alapján, fejlődési potenciált jelenthet.

4. A határon átívelö, regionális felsőoktatás- és tudományszervezés európai uniós és kárpát-medencei tapasztalatai alapján arra a következtetésre jutottam, hogy a felsőoktatás-fejlesztés a szerb-magyar (államhatárokon átnyúló) határrégióban, egy integrációs-felzárkóztatási stratégia mentén valósítható meg. A történelmi, kulturális háttér, az egyedüli etnikai összetétel és a gazdasági racionalitás (közös érdekeltségek, intézményhasználati-erőforráskihasználási lehetőségek) segíthet a periférikus helyzet és fejlettségbeli különbségek felszámolásában. Az EGTC-k („európai területi együttmüködési csoportosulások") intézményrendszere - a felsőoktatás és kutatás kivételesen fontos (kohéziós, uniós ágazatpolitikai) és regionális fejlesztési szerepe miatt - a határon átívelő felsőoktatási együttműködések modern, európai szemléletű (nemzetállami kontrolltól független) fejlesztési kerete lehet (európai példák: „Pyrenees Mediterranean” Eurocampus [katalán-francia-spanyol], „HelsinkiTallin Science Twin City" [észt-finn]).

5. Szabadka mint önálló felsőoktatási központ szerepe a régióban nem tisztázott. A helyi-regionális elit (magyar-szerb-horvát közösség) képviselői, az állami bürokrácia, akadémiai oligarchia, a piac résztvevői és további stakeholdereket szerepét megtestesítve, eltérő véleménnyel rendelkeznek Szabadkáról. Kiforrott és kidolgozott koncepció nincs. Nehezen találnak közös nevezőt „a felsőoktatás hatalmi harcát vívó" érdekcsoportok, így egy új intézmény alapításának támogatottsága bizonytalan. A potenciális támogatók: a Magyar Nemzeti Tanács, a Horvát Nemzeti Tanács, a magánkarok, Szabadka városvezetése és a civil tudományos mühelyek, valamint az egyház néhány képviselője. Az akadémiai oligarchia (,újvidéki függőség”) nem támogatja az intézményalapítást, a politikai körök várakozó állásponton vannak, kimért viselkedést tanúsítanak (Vajdasági Magyar Szövetség, Demokrata Párt).

6. Felvetésem az intézményfejlesztést támogató helyi-regionális elit véleményével támasztom alá, amely értelmében Szabadkán egy multietnikus alapokon szerveződő, állami alapítású intézménynek van létjogosultsága (ellenségkép 
formálása nélkül, versenyképességre, racionalitási, fenntarthatósági érvekre alapozva). A mintegy $\mathbf{5 0 0} 000$ fös többnemzetiségü közösség a térségben rendelkezik csak az alapításhoz szükséges kapacitásokkal és feltételekkel: jogi normatívák, politikai lobbi, humánerőforrás-igények (oktatók, kutatók: megközelítőleg 250 fö), potenciális hallgatók (7 500-8 000, ebből megközelítőleg a Szabadkán tanuló magyarok száma 2000 fő), forrásszabályozási fenntarthatóság. Egy „Szakstúdiumi Akadémia” „bázisintézményként” jöhet létre (amihez szükséges három tudományterület, legkevesebb öt akkreditált képzési program és két oktatási szint: szakstúdiumok, specializációs szakstúdiumok lefedésével), vajdasági magyar domináns intézményvezetési autonómiával. Az alapítás sarkalatos pontjai (kitartó egyezkedések, kompromisszumok árán) a szereplők közötti alapítói munkamegosztás biztosítása (például Szabadka városvezetése müvészeti kart/tagozatot hoz létre, a Magyar Tannyelvű Tanítóképző Kar a kétszakos tanárképzést szervezi meg [természet- és humántudományok], az egyház a vallástudományi képzési program kidolgozásán ügyködik, a Horvát Nemzeti Tanács horvát tanítók oktatását indítja el). Nélkülözhetetlen, egy nyelvi- és tehetséggondozó központ, valamint egy államilag akkreditált kutatóközpont létrehozása, az új intézmény keretein belül. Ezzel, a határ(ok) és társadalom felé nyitott, modern tudományszervezési és regionális szolgáltatói magatartásformát tud az új intézmény biztosítani, a helyi társadalomban több síkon demonstrálva „hasznosságát/szükségességét”.

7. Kutatási eredményeim igazolják, hogy az intézményi kapcsolatok/együttmúködések lehetőségei nincsenek kellőképpen kihasználva, mert nincs racionális és reális munkamegosztás, erőforrás-kihasználás és hálózatszerúen müködtetett együttműködés a szerb-magyar határrégióban. $\mathrm{Az}$ együttműködések tartalma tradicionális (tanár-diákcsere, konferenciarészvételek), hiányzik az innovatív $\mathrm{CBC}$ együttmüködési tartalom (közös diplomakiadás, hálózatszerü, többszereplős kutatási projektek). A nagy, patinás intézmények együttműködési hajlama inkább a nagy intézményi centrumok felé gravitál (Budapest, Belgrád), a kis és fiatal intézmények, szakfőiskolák viszont szerteágazóbban keresik a regionális együttmüködések lehetőségeit, amelyben a személyi kapcsolatok a meghatározóak (legerősebb a Szabadka székhelyü, magyar érdekeltségü intézmények integrációs szándéka).

\section{Intézményfejlesztési javaslatok}

Szabadkán, az intézményalapítást támogató érdekcsoportokon belüli „közös nevező” meghatározásával lehetséges megindítani. Jelen pillanatban ezek a Magyar Nemzeti Tanács, a Horvát Nemzeti Tanács, a magánkarok, az egyház és Szabadka város. A kutatási eredmények alapján bizonyítottam, hogy a szabadkai önálló felsőoktatási intézmény létrehozásában, mind a három érintett nemzetiség (magyar-szerb-horvát/bunyevác) szeretne részt és szerepet vállalni, pontosabban megtalálni helyüket az intézményen belül, így egy multietnikus intézmény jöhet majd létre (ellenségkép formálása nélkül, továbbá racionalitási, fenntarthatósági érvek biztosításával). Az intézménynek egy többnemzetiségü közösség (kb. 500000 fö) felsőoktatási igényét kell kielégítenie. 
(Meg)ismerve a helyi intézmények (és a többi szereplö, érdekcsoport) álláspontját, a probléma relevanciáját, egy megoldási javaslatot szeretnék tenni, amely konstruktív lehet a régió felsőoktatása (és a kisebbségi közösség) számára egyaránt:

Mivel jelen pillanatban az intézményalapítást a Magyar Nemzeti Tanács tűzte zászlójára (2012 decembere), így egy MNT-Szabadka város-Tartomány reláción kialakuló, politikai támogatottság mellett valósítható meg az alapítás. Ezt a politikai döntést meg kell hozni, majd ezt követően meg kell kezdeni a tárgyalásokat, amelyek során, a konszenzuson alapuló intézményalapítás feltételei és lépései a következők:

- MNT magára vállalja az alapitás kezdeményezését; Szakstúdiumi Akadémiát alapit, mivel a lehetőségek középtávon ehhez adottak. A koncepció létjogosultsága a határon átívelő régió (EGTC intézményrendszer és CBC programok) esetében sem vitatható el. Egy olyan „, bázisintézmény” jön létre, amely (belső jogi szabályozása alapján) önmaga kezdeményezi az együttmüködéseket, ugyanakkor nem verseng sem Újvidékkel, sem Szegeddel, sokkal inkább a közös erőforrások megosztására helyezi a hangsúlyt. Az intézmény folyamatosan és alacsonyabb (kevésbé restriktív jogi) feltételek mellett tud képzési programokat bevezetni, míg magasabb szintű képzést (doktori képzés) nem akkreditál. Helyette $C B C$ lehetőségekre épít (Magyarország, Horvátország, más országok), elkerülve a belterjességet és nihilizmust. Egy egyedi szervezési forma mentén történik az új intézmény megalapítása (a gyakorlatban erre még nincs példa), egyedi névvel, brendesítve Szabadkát, Szabadka felsőoktatását.

- Alapítványt kell létrehozni (a Magyar Nemzeti Tanácson belül), amely a „szabadkai önálló felsőoktatási intézmény” megalapításának feladatait fogja lemenedzselni (támogatások-pénzügyek, intézményi kapcsolatok, tanárok), kommunikálva a városvezetéssel, tartománnyal, a magyar kormánnyal. Továbbá akkreditációs és képzési programfejlesztö irodát és pályázati irodát kell létrehozni.

- MNT folyamatosan egyeztet a magyar érdekeltségü intézményekkel (Magyar Tannyelvű Tanítóképző Kar, Szabadkai Műszaki Szakfőiskola, Óvóképző Szakföiskola, BCE Kertészettudományi Kara), a tartományi szervekkel és a városvezetéssel.

- Szabadka városvezetése támogatja az alapítást, és kitámogatja a harmadik tudományterületet lefedő kar/tagozat megalapítását, nevezetesen alapít egy müvészeti kart/tagozatot (ide betagosodik az Újvidéki Művészeti Akadémia magyar dráma tanszéke is). A városvezetés infrastrukturális feltételek biztosításában is közbenjár (ingatlan, felszerelések).

- A Magyar Tannyelvü Tanitóképzö Kar magára vállalja a kétszakos tanárképzés (természet- és humántudományokat lefedő képzési programok) elindítását.

- A Horvát Nemzeti Tanács az új intézményen belül megszervezi a saját tanitóképzési programot, esetleges kroatisztika tanszéket hoz létre az intézményesülő pedagógiai karon/tagozaton belül.

- Az egyház a vallástudományi képzési terület lefedését biztosító képzési programmal járul hozzá az új intézmény alapításához.

- A BCE Kertészettudományi Kar felméri és elindítja az önálló intézmény (agrár- és kertészettudományi mérnöki képzés) akkreditációjához szükséges feltételek megvalósitási lehetőségeit (a lassan 20 éve müködő kihelyezett képzés leválásával).

- Annak ellenére, hogy a magánkarok irányában nagy ellenállás mutatkozik, szükség van az érdekelt magánintézmények bekapcsolására is (ha azzal a képzési programok bővíthetők). Menedzserképzés (sokkal inkább alkalmazott gazdasági: könyvelöi, vállalkozói programokkal) müködtetésére a FABUS-magánkar 
bekapcsolása lehet megoldás, elkerülve a munkaerö-piaci túlképzést és diplomadömpinget.

- Egy szerb, horvát, angol, német és egyéb idegen nyelvek oktatását megszervezö nyelvi központ létrehozása (a magyar nemzetiségü hallgatók számára [szerb nyelvből] kötelező jelleggel [vizsgakötelezettséggel, szemeszterhitelesítési feltételrendszerrel]) szintén nélkülözhetetlen része a felsőoktatás-fejlesztési koncepciónak.

- Az önálló felsőoktatási intézményben a kutatói perifériák is helyet kell, hogy kapjanak, így egy kutatóintézet létrehozása, akkreditálása szükséges. Erre több okból is szükség van: (1.) össze kell vonni a már meglévő, atomizálódott kutatói mühelyeket, (2.) tekintettel arra, hogy a legtöbb fiatal kutató társadalomtudományi végzettségü, az önálló felsőoktatási intézmény mellett, a fiatalok bevonásával akkreditáltatni kell egy multidiszciplináris kutatói központot. Itt tudományos kutatómunka folyna több tudományterületen: közgazdaság- és regionális kutatások, politológia, szociológia, közigazgatás, jog, kisebbségkutatás, antropológia, néprajz, nyelvészet, bölcsésztudományok, történelem, hittudományok, stb.

Hosszabb távon lehetőség lenne arra, hogy egyetemmé alakuljon át az intézmény. Ehhez biztosítani kell a szabadkai magyar érdekeltségü intézmények folyamatos fejlesztését (stratégiai tervezés), építését, kari szintre emelését, a későbbi egyetem akkreditálásához (ezek közül prioritást élveznek: pedagógiai kar és kétszakos tanárképzés, politechnikai kar, agrár- és környezetgazdálkodási-biogazdálkodási kar, müvészeti kar). Az oktatás megszervezése (és a tudományterületi lefedettség, a tanerő-utánpótlás) szempontjából hiányzó, tudományos fokozattal rendelkező humánerőforrás folyamatos támogatására, az oktatói gárda kinevelésére van szükség, ebben a magyar érdekeket a Magyar Nemzeti Tanács és a Vajdasági Magyar Felsőoktatási Kollégium kell, hogy képviseljék (ahol anyaországi támogatásokra is szükség van: doktori képzések, ösztöndíjak). Továbbá komoly, belső humánerőforrás-fejlesztési program kell (konkrét publikációs és kutatói feltételrendszer oktatónként), ugyanis probléma, hogy az oktatók nehezen tudnak majd akadémiai karriert és elörehaladást megvalósítani a szakstúdiumi akadémián belül (nincs átjárhatóság a szakstúdiumok és akadémiai stúdiumok között).

A helyi regionális elit megszólaltatott képviselői hangsúlyozzák: rugalmas, nyitott „egyetem” kell, amely a gazdasággal, munkaerőpiaccal is képes együttmüködni, biztosítva nem csak az oktatás, de a tudománymüvelés területén is. A kínálat színesítésében a határon átívelö együttmüködésekben rejlö lehetőségeket kell kihasználni, ez hozhat nagyobb előrehaladást, következetesen, az eddig implementált stratégiai fejlesztési célokra (Magyar Nemzeti Tanács: Oktatási stratégia) épülve. A határon túli intézményekkel (alapítványi irányítással) történő kapcsolatfelvétel nélkülözhetetlen, hiszen ezek az intézmények - a „bázisintézmény” megalapítását követően - a rugalmas és változatos programok biztosításával tudnak hozzájárulni az intézmény hosszú távú fejlődéséhez.

\section{Hivatkozások}

ALTBACH, PHILIP G.-KNIGHT, JANE 2011: The Internationalization of Higher Education. Motivations and Realities. In: TIGHT, MALCOLM (szerk.): Higher Education. Major Themes in Education. III. System Policy. Abingdon, Routledge. 3-18. o.

CLARK, BURTON 1983: The Higher Education System: Academic Organization in Cross-National Perspective. Berkeley, University of California Press. 
COLLINS, CHRISTOPHER S. 2011: Cross-Border Collaboration in the Service of Human Capacity Development. In: SAKAMOTO, ROBIN-CHAPMAN, DAVID W. (szerk.): Cross-border Partnership in Higher Education. Strategies and Issues. New York, Routledge. 228-247. o.

DENMAN, BRIAN D. 2011: What is a University in the 21st Century? In: TIGHT, MALCOLM (szerk.): Higher Education. Major Themes in Education. V. Academic Work, Knowledge and Research. Abingdon, Routledge. 423-441. o.

EDUCATIO 2012: Budapest, Educatio Társadalmi Szolgáltató Nonprofit Kft. [statisztikai adatbázis]

GÁBRITY MOLNÁR IRÉN 2005: Magyar vagy multietnikus egyetem alapításának indoklása Vajdaságban. In: KONTRA MIKLÓS (szerk.): Sült galamb? Magyar egyetemi tankönyvpolitika. Somorja-Dunaszerdahely, Forum. 211-228. o.

GÁBRITY MOLNÁR IRÉN 2006: A vajdasági magyar felsőoktatás szerveződése. In: JUHÁSZ ERIKA (szerk.): Régió és oktatás. A „Regionális egyetem” kutatás zárókonferenciájának tanulmánykötete. Debrecen, Doktoranduszok Kiss Árpád Közhasznú Egyesülete. 105-113. o.

GÁBRITY MOLNÁR IRÉN 2008: Oktatásunk látlelete. Újvidék-Szabadka, Fórum, Újvidéki Egyetem, MTTK.

GODDARD, JOHN 2008: The Role of the University in the Development of its City and Region. Newcastle University [Public Lecture], 1-19. o.

HORVÁTH GYULA 2003: Európai regionális politika. Budapest-Pécs, Dialóg Campus Kiadó.

HORVÁTH GYULA 2006: Regionális helyzetkép a Kárpát-medencéről. In: RÁCZ SZILÁRD (szerk.): Regionális átalakulás a Kárpát-medencében. Pécs, MRTT. 922. 0 .

HORVÁTH GYULA 2010: Felsőoktatás, kutatás és fejlesztés. In: HORVÁTH GYULAHAJDÚ ZOLTÁN (szerk.): Regionális átalakulási folyamatok a Nyugat-Balkán országaiban. Pécs, MTA RKK. 471-489. o.

HRUBOS ILDIKÓ 2011: A diverzifikált felsőoktatási rendszer értelmezése Európában. In: BERÁCS JÓZSEF-HRUBOS ILDIKÓ-TEMESI JÓZSEF (szerk.): „Magyar Felsöoktatás 2010”. Konferencia dokumentumok. Budapest, BCE KK, NFKK. 8790. o.

HRUBOS ILDIKÓ 2012: Intézményi missziók, intézménytípusok a felsőoktatásban. In: BERÁCS JÓZSEF-HRUBOS ILDIKÓ-TEMESI JÓZSEF (szerk.): „Magyar Felsőoktatás 2011" Hazai vitakérdések-nemzetközi trendek. Konferencia dokumentumok. Budapest, BCE KK, NFKK. 78-91. o.

HUGGINS, ROBERT-JOHNSTON, ANDREW 2009: The Economic and Innovation Contribution of Universities: A Regional Perspective. - Government and Policy EPC. 27. évf. 6. sz. 1088-1106. o.

KNIGHT, JANE 2011: Higher Education Crossing Borders. A Framework and Overview of New Developments and Issues. In: SAKAMOTO, ROBIN-CHAPMAN, DAVID W. (szerk.): Cross-border Partnership in Higher Education. Strategies and Issues. New York, Routledge, 16-41. o.

KOZMA TAMÁS 2002: Regionális Egyetem. Budapest, OKI.

KOZMA TAMÁS 2003: Változások hordozói. Kisebbségi felsőoktatási kezdeményezések Közép-Európában. - Educatio 1. sz. 65-78. o. 
KOZMA TAMÁS 2004: Kié az egyetem? A felsőoktatás nevelésszociológiája. Budapest, ÚMK.

KOZMA TAMÁS (szerk.) 2005: Kisebbségi oktatás Közép-Európában. Budapest, ÚMK. 170-178. o.

PAPP Z. ATTILA 2006: Határon túli magyar oktatástámogatások. - Educatio. 1. sz. 130146. o.

PAPP Z. ATTILA 2010a: Határon túli magyar oktatási támogatások és hasznosulásuk 2006-2010 között. - Educatio. Mérleg 2006-2010. 19. évf. 1. sz. 88-110. o.

PAPP Z. ATTILA 2010b: A Kárpát-medencei kisebbségi magyar felsőoktatás kihívásai. Felsöoktatási Mühely. 3. sz. 79-92. o.

PAPP Z. ATTILA 2012: Kisebbségi magyarok oktatási részvételének értelmezési lehetőségei. - Educatio. Magyar kisebbségek az oktatásban. 21. évf. Tavasz. 3-23. o.

RECHNITZER JÁNOS-HARDI TAMÁS (szerk.) 2003: A Szent István Egyetem hatása a régió fejlődésére. Győr, SZIE Gazdaság- és Társadalomtudományi Intézet.

RECHNITZER JÁNOS-SMAHÓ MELINDA 2007: Interregionális, határ menti kapcsolatok. In: RECHNITZER JÁNOS-SMAHÓ MELINDA (szerk.): Unirégió Egyetemek a határ menti együttmüködésben. Pécs-Györ, MTA RKK. 52-71. o.

RECHNITZER JÁNOS 2011: A felsőoktatás tere, a tér felsőoktatása. In: BERÁCS JÓZSEF-HRUBOS ILDIKÓ-TEMESI JÓZSEF (szerk.): „Magyar Felsőoktatás 2010”. Konferencia dokumentumok. Budapest, BCE KK, NFKK. 70-86. o.

SAKAMOTO, ROBIN-CHAPMAN, DAVID W. 2011: Expanding Across Borders. Growth of Cross-border Partnership in Higher Education. In: SAKAMOTO, ROBIN-CHAPMAN, DAVID W. (szerk.): Cross-border Partnership in Higher Education. Strategies and Issues. New York, Routledge. 3-15. o.

SALAT LEVENTE 2012: Kisebbségi egyetemek a világ néhány térségében. - Educatio. Magyar kisebbségek az oktatásban. 21. évf. Tavasz. 49-66. o.

SCOTT, PETER 2011: Higher Education in Central and Eastern Europe. In: FOREST, JAMES J. F.-ALTBACH, PHILIP G. (szerk.): International Handbook of Higher Education. Part Two: Regions and Countries. Dordrecht-Heidelberg-London-New York, Springer. 423-441. o.

TEICHLER, ULRICH (2003): The Future of Higher Education and the Future of Higher Education Research. - Tertiary Education and Management. No. 9. 171-185. o.

TEICHLER, ULRICH (2011): Changing Structures of the Higher Education Systems. The Increasing Complexity of Underlying Forces. In: TIGHT, MALCOLM (szerk.): Higher Education. Major Themes in Education. III. System Policy. Abingdon: Routledge. 19-33. o.

\section{A szerző önéletrajza, kutatási témához kapcsolódó publikációi és tudományos munkája}

TAKÁCS ZOLTÁN - 1982-ben született Zentán. Jelenleg Magyarkanizsán él és dolgozik, a Magyarkanizsai Egészségház számviteli osztályának vezetőjeként (2006-tól). Tartományi parlamenti képviselő (2012-től). A Vajdasági Magyar Doktoranduszok és Kutatók 
Szervezetének alelnöke (2011-től). Okleveles közgazdász. Diplomát az Újvidéki Egyetem Szabadkai Közgazdasági Karán szerez 2006-ban. Tanulmányait a Pécsi Tudományegyetem Közgazdaságtudományi Karán folytatja 2006-tól, a Pécsi Regionális Politika és Gazdaságtan Doktori Iskolában, 2009-től doktorjelölt. Kutatási témája: Regionális felsőoktatás (témavezető: Prof. Dr. Horváth Gyula; társkonzulens: Prof. Dr. Gábrity Molnár Irén). További kutatási területek: kisebbségi társadalmi kérdések, határrégiók, migráció, regionális gazdaság és regionális politika. A szerb nyelv mint környezetnyelv mellett felsőfokú német és angol nyelvtudással rendelkezik. A TEMPUS program ösztöndíjasa 2005-ben (Ekonomski Fakultet Univerziteta Crne Gore, PodgoricaMontenegró), majd a „Dr. Zoran Đinđici“ Alapítvány és a „Német Gazdaság Keleti Bizottságának" ösztöndíjasa a 2005-ös évben (Düsseldorf-Németország). Kutatásait a Szabadkai Regionális Tudományi Társaság ösztöndíjasaként folytatja (2006-2009, Szabadka-Szerbia) és a szabadkai székhelyü Magyarságkutató Tudományos Társaság projektmunkáiban vesz részt, 2006-tól folyamatosan. A Magyar Köztársaság Oktatási és Kulturális Minisztériuma és a Balassi Intézet Elitkollégiumának ösztöndíjasa (2008-2009, Budapest-Magyarország), továbbá Domus Hungarica ösztöndíjas (2009, 2010, 2011 Budapest-Magyarország). 2009-ben és 2010-ben a Határon Túli Magyar Tudományos Ösztöndíjprogram résztvevője (Budapest-Magyarország). 2011-ben SCOPES-ösztöndíjas (Berni Egyetem, Bern-Svájc), majd 2012-ben a Német Akadémiai Csereprogram ösztöndíjasa (DAAD, Lipcse-Németország). A disszertáció témájához kapcsolódó publikációk (magyar, angol, német és szerb nyelven), valamint hazai és nemzetközi konferencia-részvételek, hazai és nemzetközi kutatási projektekben való részvétel jegyzéke:

\section{Publikációk:}

TAKÁCS ZOLTÁN 2007: A Vajdaság mint régió - regionális folyamatok Szerbiában a munkaerő-kompetencia és az oktatás viszonya szempontjából. - Kitekintés. Perspective. 11. évf. 12. sz. 190-197. o.

TAKÁCS ZOLTÁN 2008: A munkaerö-kompetencia és az oktatás viszonya. In: GÁBRITY MOLNÁR IRÉN-MIRNICS ZSUZSA (szerk.): Regionális erőnlét. A humáneröforrás befolyása Vajdaságban. Szabadka, MTT. 267-292. o.

TAKÁCS ZOLTÁN 2008: A vajdasági régió felsőoktatásának helyzetelemzése perspektívák, jövőalternatívák néhány tézis erejéig. Magyarok a Kárpátmedencében. Tudományos nemzetközi konferencia, Szeged. [Konferencia CD]

TAKÁCS ZOLTÁN 2008: A felsőoktatás regionális dimenziói a Vajdaságban. In: BUDAY-SÁNTHA ATTILA-ZEMPLÉNYINÉ BARTHA JÚLIA (szerk.): Évkönyv 2008. PTE KTK Regionális Politika és Gazdaságtan Doktori Iskola. Pécs, PTE KTK. 271-283. o.

TAKÁCS ZOLTÁN 2008: A szerb oktatási rendszer lokális kompetenciáinak mérlege regionális fejlesztési távlatok. In: BUDAY-SÁNTHA ATTILA-HEGYI JUDITRÁCZ SZILÁRD (szerk.): Önkormányzatok gazdálkodása - helyi fejlesztések. Pécs, PTE KTK. 389-394. o.

TAKÁCS ZOLTÁN 2008: Egészségügy, egészségügyi szakoktatás. In: GÁBRITY MOLNÁR IRÉN (szerk.): Képzetteké a jövő. A felnőttképzés háttere Észak-Bácska iskolahálózatában. Szabadka, RTT. 129-139. o., 189-196. o.

TAKÁCS ZOLTÁN 2008: BARLAI JENÖ-GÁBRITY MOLNÁR IRÉN (szerk.): Hazaérsz. Esély és esélyegyenlöség a Vajdaságban. Szabadka, Vajdasági Módszertani Központ. 156. o. [recenzió] 
TAKÁCS ZOLTÁN 2009: Munkaerő-kompetencia és a felnőttképzés kapcsolata. In: SARNYAI KÁROLY (szerk.): Esélyt adó felnöttképzés. Magyarkanizsa, Cnesa Oktatási Müvelődési Intézet. 21-32. o.

TAKÁCS ZOLTÁN 2009: Regionális felsőoktatás - Vajdaság. In: KÖTÉL EMÖKE (szerk.): Ph. D. konferencia. A Tudomány Napja tiszteletére rendezett konferencia tanulmányaiból. Budapest, Balassi Intézet Márton Áron Szakkollégium. 177-198. o.

TAKÁCS ZOLTÁN 2009: Egyetemalapítási helyzetkép a Délvidéken. In: KÖTÉL EMŐKE-SZARKA LÁSZLÓ (szerk.): Határhelyzetek II. Kultúra-Oktatás-NyelvPolitika. Budapest, Balassi Intézet Márton Áron Szakkollégium. 289-313. o.

TAKÁCS ZOLTÁN 2009: Oktatási intézetek tudástranszfer hatásának vizsgálata Vajdaságban. In: SOMOGYI SÁNDOR (szerk.): Évkönyv 2008. Regionális Tudományi Társaság. Szabadka, RTT. 201-222. o.

TAKÁCS ZOLTÁN 2009: A felnőttképzés mint regionális társadalmi igény. DETUROPE. The Central European Journal of Regional Development and Tourism. 1. évf. 1. sz. 165-184. o.

SOMOGYI SÁNDOR-RICZ ANDRÁS-KAJÁRI KAROLINA-GÁBRITY MOLNÁR IRÉN-LAKNTER ZOLTÁN-TAKÁCS ZOLTÁN-CSISZÁR-MOLNÁR ANNA 2010: Strukturne karakteristike i potencijali razvoja ljudskih resursa vezano za proces pridruživanja EU u severnom delu Autonomne Pokrajine Vojvodine (Subotica, Bačka Topola, Mali Iđoš, Kanjiža, Senta, Ada, Bečej, Čoka). In: SOMOGYI SÁNDOR (szerk.): Évkönyv 2009. Regionális Tudományi Társaság Szabadka. Szabadka, RTT. 86-110.

TAKÁCS ZOLTÁN 2010: Egyetemalapítási helyzetkép a Délvidéken. Abszolutóriumi dolgozat - összegzés. In: SOMOGYI SÁNDOR (szerk.): Évkönyv 2009. Regionális Tudományi Társaság. Szabadka, RTT. 61-85. o.

TAKÁCS ZOLTÁN 2010: A munkanélküliség nemzet- és regionális-gazdasági sajátosságai Szerbiában. - DETUROPE. The Central European Journal of Regional Development and Tourism. 2. évf. 2. sz. 128-163. o.

TAKÁCS ZOLTÁN 2010: Regionális igényeket szolgáló egészségügyi szakoktatás, felnőttképzés jelene, jövője az észak-vajdasági régióban. - DETUROPE. The Central European Journal of Regional Development and Tourism. 2. évf. 1. sz. 102-125. o.

PÁL ÁGNES-TAKÁCS ZOLTÁN 2011: A Vajdaság társadalmi-gazdasági helyzetének változásai és regionális sajátosságai napjainkban. - Közép-Európai Közlemények. Történészek, geográfusok és regionalisták folyóirata. 4. évf. 3-4. sz. 156-165. o.

SZÜGYI ÉVA-TAKÁCS ZOLTÁN 2011: Menni vagy maradni? Esélylatolgatás szerbiai és magyarországi diplomával a Vajdaságban In: PÁGER BALÁZS (szerk.) Évkönyv 2011. Regionális Politika és Gazdaságtan Doktori Iskola. Pécs, PTE KTK. 283-300. o.

SZÜGYI ÉVA-TAKÁCS ZOLTÁN 2011: Migrációs karrierkövetési vizsgálatok a vajdasági magyar fiatal közgazdászok és mérnökök körében. - DETUROPE. The Central European Journal of Regional Development and Tourism. 3. évf. 3. sz. 6684. o.

TAKÁCS ZOLTÁN 2011: Felsőoktatási intézménykapcsolatok egy határral szabdalt régióban. In: GÁBRITY MOLNÁR IRÉN (szerk.): Magyarságkutatás Vajdaságban. Szabadka, MTT. 128-150. o. 
TAKÁCS ZOLTÁN 2012: Regionális és határon átívelő felsőoktatási intézménykapcsolatok és együttmüködések Észak-Vajdaságban. - Educatio. Magyar kisebbségek az oktatásban. 21. évf. Tavasz. 104-122. o.

TAKÁCS ZOLTÁN-GÁBRITY MOLNÁR IRÉN 2012: Karrierutak, érvényesülési pályák, emigráció a vajdasági magyar doktoranduszok körében. In: TAKÁCS MÁRTA (szerk.): Évkönyv. Szabadka, ÚE MTTK. 7. évf. 1. sz. 180-190. o.

TAKÁCS ZOLTÁN-KINCSES ÁRON 2013: A Magyarországra érkező külföldi hallgatók területi jellegzetességei. - Területi Statisztika. 53. évf. 1. sz. 38-53. o.

TAKÁCS ZOLTÁN-KINCSES ÁRON 2013: Vajdasági hallgatók Magyarországon. Területi Statisztika. 53. évf. 3. sz. 253-270. o.

TAKÁCS ZOLTÁN-TÁTRAI PATRIK-ERŐSS ÁGNES 2013: A Vajdaságból Magyarországra irányuló tanulmányi célú migráció. - Tér és Társadalom. 2. sz. 77-95. o.

BÉLA FILEP-MONIKA M. VÁRADI-ZOLTÁN TAKÁCS-ÁGNES ERŐSS-IMRE NAGY-PATRIK TÁTRAI-DORIS WASTL-WALTER 2013: Ungarische Migranten in Ungarn: Deserteure, Studierende und Berufstätige aus der Woiwodina zwischen transnationaler und ethnischer Migration. - MÖGG Mitteilungen der Österreichischen Geographischen Gesellschaft. 155. sz. 1-23. o.

ДОРИС, ВАСТЛ-ВАЛТЕР-МОНИКА ВАРАДИ-ЗОЛТАН ТАКАЧ: Транснационалне миграције и прекогранична мобилност у пограничном региону Србија-Мађарска. - Анали Економског Факултета у Суботици [megjelenés alatt].

TAKÁCS ZOLTÁN: Magyar felsőoktatás és tudományszervezés a Vajdaságban. In: „, Oktatási Kataszter 2010”. Márton Áron Szakkollégium. [megjelenés alatt]

ZOLTÁN TAKÁCS-ESZTER GÁBRITY: Development of Higher Education Networking in Multiethnic Border Region of North Vojvodina. In: The New European Frontiers Social and Spatial (Re)Integration Issues in Multicultural and Border Regions. Institute for Geographical Studies, Koper, Cambridge Scholars Publishing [megjelenés alatt].

\section{Konferencia-előadások:}

TAKÁCS ZOLTÁN 2008: A szerb oktatási rendszer lokális kompetenciáinak mérlegeregionális fejlesztési távlatok. „Önkormányzatok gazdálkodása - helyi fejlesztés”. PTE Regionális Politika és Gazdaságtan Doktori Iskola: Magyarország, Pécs. [2008. május 16-17.]

TAKÁCS ZOLTÁN 2008: A regionális igényeket szolgáló egészségügyi szakoktatás, felnőttképzés jelene, jövője az észak-vajdasági régióban. „Határtalan határok”Tudományos földrajzi konferencia: Magyarország, Dobogókő. [2008. október 2627.]

TAKÁCS ZOLTÁN 2008: Regionális felsőoktatás Vajdaság. Ph.D konferencia. A Tudomány Napja tiszteletére rendezett konferencia. Balassi Intézet Márton Áron Szakkollégium: Magyarország, Budapest. [2008. november 10.]

TAKÁCS ZOLTÁN 2009: A munkaerö-kompetencia és a felnöttképzés kapcsolata. Esélyt adó felnőttképzés. Cnesa OMI: Szerbia, Magyarkanizsa/Kanjiža. [2009. március 28.] 
TAKÁCS ZOLTÁN 2011: Student Mobility or Emigration Flow? The Case of Students Commuting from Serbia to Hungary. Border Regions in Transition (BRIT) XI.: Switzerland/France, Geneva/Grenoble. [2011. szeptember 6-9.]

ZOLTÁN TAKÁCS-ESZTER GÁBRITY 2011: Development of Higher Education Networking in Multiethnic Border Region of North Vojvodina. (Re)Integration and Development Issues in Multicultural and Border Regions: Slovenia, Portorož. [2011. Szeptember 22-24.]

TAKÁCS ZOLTÁN 2011: Regionális és határon átívelő felsőoktatási intézménykapcsolatok és együttmüködések Észak- Vajdaságban. Magyar Szociológiai Társaság, Kisebbségi magyarok: Magyarország, Miskolc. [2011. november 11-13.]

TAKÁCS ZOLTÁN 2011: Határon átívelö felsőoktatási kapcsolatok. IX. Vándorgyülés, Magyar Regionális Tudományi Társaság: Szlovákia, Révkomárom. [2011. november 24-26.]

TAKÁCS ZOLTÁN 2011: Felsőoktatási intézménykapcsolatok egy határral szabdalt régióban. A kisebbségkutatás 20 évének állomásai. MTT: Szerbia, Szabadka. [2011. december 17.]

ANDREAS WINKLER-TAKÁCS ZOLTÁN 2012: Regional Policy and Regional Disparities. Institutionalisation of Spatial Development in Serbia with Focus on the Autonomous Province of Vojvodina. 32rd International Geographical Congress (IGC): Germany, Cologne. [2012. augusztus 26-30.]

ESTER GABRIC-ZOLTAN TAKAC 2012: Language Divided by Border. Border and Language Consciousness among Hungarian Migrants and Labor Migrants between the Serbian-Hungarian Borders. Borders and Borderlands. Today' Challenges and Tomorrow's Prospects. Assosiation for Borderland Studies (ABS): Portugal, Lisbon. [2012. szeptember 12-15.]

ZOLTAN TAKAČ 2012: Prekogranične institucionalne mreže. Srpsko-mađarski prekogranični kontakti i stil života migranata. TRANSMIG: Srbija, Subotica. [2012. december 4.]

TAKÁCS ZOLTÁN 2013: A felsöoktatás fejlesztésének lehetőségei Szabadkán. Tudományos diszkurzusok. Vajdasági magyar tudóstalálkozó 2013. Újvidéki Egyetem, MTTK: Szerbia, Szabadka/Subotica. [2013. április 13.]

TAKÁCS ZOLTÁN 2013: Szabadka felsőoktatása határon átívelö, regionális- és társadalomgazdasági kontextusban. „Felelő(s) közösségek” konferencia. Baranya Megyei Önkormányzat-Pécsi Tudományegyetem: Magyarország, Pécs. [2013. május 22-24.]

\section{Tudományos-kutatási projektek:}

2008-2009 Egyetemalapítási helyzetkép a Délvidéken; A Magyar Köztársaság Oktatási és Kulturális Minisztériuma és a Balassi Intézet pályázata: Magyarország, Budapest. [Önálló kutatói ösztöndíj]

2009 Egyetemkutatás; „Oktatásrégió koncepció” kutatási projekt (RTT, Szabadka), Szülőföld Alap: Magyarország, Budapest. [kutató]

2009 Egyetemalapítási lehetőségek a Vajdaságban; A Magyar Tudományos Akadémia ösztöndíja: „A Határon Túli Magyar Tudományosságért Ösztöndíj Program": Magyarország, Budapest. [Önálló kutatói ösztöndíj] 
2009-2010 Strukturne karakteristike i potencijali razvoja ljudskih resursa vezano za proces pridruživanja EU u severnom delu Autonomne Pokrajine Vojvodine; Regionális Tudományi Társaság, Szabadka-Centar za Strateško ekonomska istraživanja „Vojvodina CESS”, Novi Sad-Austrian Development Agency (ADA), Wien. [kutató]

2010 Az észak-vajdasági régió társadalom-gazdasági sajátosságai a potenciális egyetemalapítás szemszögéböl; A Magyar Tudományos Akadémia ösztöndíja: „A Határon Túli Magyar Tudományosságért Ösztöndíj Program": Magyarország, Budapest. [Önálló kutatói ösztöndíj]

2010 Magyar-magyar határokon átívelö felsőoktatás; „Domus Hungarica Scientiarum et Artium” Ösztöndíjprogram, Magyar Tudományos Akadémia, Etnikai-Nemzeti Kisebbségkutató Intézet: Magyarország, Budapest. [Önálló kutatói ösztöndíj]

2010 „Oktatási Kataszter 2010”. A Kárpát-medence magyar oktatási és tudományos intézményeinek adatbázisa; (Magyarságkutató Tudományos Társaság, Szabadka), Márton Áron Szakkollégium, Kutatások Koordinációs Irodája: Magyarország, Budapest. [kutató]

2010-2011 Education and Youth Research. The Borderline as an Axis of Innovation, IPA; MTA Regionális Kutatások Központja, Pécs, MTA RKK ATI Kecskeméti Osztálya-Regionális Tudományi Társaság, SzabadkaMórahalom Önkormányzat. [kutató]

2011 Tanulási célú migráció a Kárpát-medencében; „Domus Hungarica Scientiarum et Artium" Ösztöndíjprogram, Magyar Tudományos Akadémia, Földrajztudományi Kutatóintézet: Magyarország, Budapest. [Önálló kutatói ösztöndíj]

2010-2013 Integrating (Trans)national Migrants in Transition States (TRANSMIG); Joint research project in the framework of SCOPES (Scientific Cooperation between Eastern Europe and Switzerland): Department of Geography, University of Bern (Bern, Switzerland), Geographical Research Institute, Hungarian Academy of Sciences (Budapest, Hungary), Centre for Regional Studies, Hungarian Academy of Sciences (Pécs, Hungary), Department of Geography, Tourism \& Hotel Management, University of Novi Sad (Novi Sad, Serbia), Scientific Association for Hungarology Research (Subotica, Serbia). [kutató]

2013 A Szabadkai Müszaki Szakfőiskola Intézményfejlesztési Terve; Emberi Erőforrások Minisztériuma: Magyarország, Budapest. [kutatásvezető] 